\title{
Module of Writing Proposal Based on Problem Based Learning
}

\author{
R Fitri ${ }^{1}$, R G Tatalia ${ }^{2}$, R Sartika $^{3}$, U Yulianti ${ }^{4}$, R Yulisna $^{5}$, R L Tiawati R. ${ }^{6}$ \\ $1,2,3,4,5$ STKIP PGRI Sumatera Barat
}

\begin{abstract}
\{rahayu@stkip-pgri-sumbar.ac.id ${ }^{1}$, ricci@stkip-pgri-sumbar.ac.id ${ }^{2}$,rina@stkip-pgri-sumbar.ac.id ${ }^{3}$, upit@stkip-pgri-sumbar.ac.id ${ }^{4}$, risa@stkip-pgri-sumbar.ac.id ${ }^{5}$, refa@stkip-pgri-sumbar.ac.id ${ }^{6}$ \}
\end{abstract}

\begin{abstract}
This study aims to develop a valid, practical, and effective learning module basedon Problem Based Learning for writing proposals in achieving learning goals for students of class XI SMA/MA. This type of research is research and development (R\&D) with 4-D model. In this study, the development model is modified into a 3-D which includes the step of define, design, and development. The type of this research is quantitative consisting of three kinds of data, namely data from validation results by experts, evaluations by practitioners, learning outcomes and student activities. The results showed that the learning module based Problem Based Learning developed was valid, practical, and effective. This can be seen in the module validity is 95,53 with very valid criteria. Module practicality by teachers is 85,46 with very practical criteria and module practicality by students is 82,1 with very practical criteria. The effectiveness of the module, which consists of student learning outcomes has a classical average is 81,9 with good qualifications and student activities have a value is 78,31 with active criteria.
\end{abstract}

Keywords: Module, PBL, Writing Proposal

\section{INTRODUCTION}

Proposals are important documents to convey ideas, ideas, thoughts, and plans to other parties to get support, permission, approval, and so on. The first impression that greatly influences the success of a plan can be determined based on the proposal submitted. The proposal is the entry point for achieving success in the future [1]. Therefore, it can be said that the proposal is the key to success.

The proposal is a form of bid submission, both in the form of ideas, thoughts, or plans to other parties to get support, permission, approval, funding, etc. [2]. Something will go well, if planned properly. So that everything goes according to plan, you will need a tool. Activities will be well planned with the proposal being made. The proposal is a framework, plan, and description of the activities to be carried out. One type of proposal is an activity proposal. The activity proposal is an activity plan prepared by the committee to get help and approval from third parties and related parties [1]. Activity proposals are submitted to individual and institutional sponsors because of the limited funds that the organizers have to obtain aid funds so that the planned activities can run smoothly. Examples of this activity proposal are proposals for seminars, training, and competitions. In the activity proposal, the 
contents/elements that must be written, namely the name of the activity/title of the proposal, rationale, purpose of the activity, benefits of the activity, theme of activity, scope of activities, schedule, time and place of activity, executive committee, budget, and cover.

Thus, the ability to write proposals is an important ability and must be mastered by students. In the Kurikulum 2013 of Indonesian language subjects at the SMA/MA level, it was stated that the ability to write proposals was one of the learning materials in class XI. The expected learning outcomes are so that students are skilled at writing proposals in accordance with the format and logic of the contents of the proposal. Proposal writing skills are able to form a creative and critical generation because they have the ability to systematically express ideas, thoughts, and feelings to others to carry out useful activities in life [3]. In addition, the language elements in writing proposals must also be considered by students. These linguistic elements include the use of spelling, diction, and sentence structure.

However, the reality found in the current class, shows that students proposal writing skills are still low. This is evidenced from the results of observations of proposals that have been written by students of class XI IPA in SMA N 1 Padang Ganting. There are many errors in the proposal. The errors are as follows. First, themistakes in writing the elements of the proposal. In other words, the elements of the proposal are not written completely by students. In addition, the elements of the proposal are also not written correctly by students. Second, errors in applying spelling rules. Third, mistakes in terms of choosing words have an impact on students' sentence ineffectiveness.

The results of writing proposals are very concerning [4]. Based on preliminary studies conducted on the results of writing proposals on class XII Pemasaran on Entrepreneurship subjects. The results of the observation indicate that students in writing proposals still have difficulty writing. Difficulties experienced by students in compiling the resulting proposal can be identified several weaknesses, namely (1) students have not been able to develop proposals in accordance with the characteristics of the proposal, (2) students have not been able to formulate the contents in accordance with the systematic proposal, (3) students' ability to use language (the accuracy of choosing words and the use of sentence structure, spelling writing is still low, (4) student learning motivation is low.

The low skill of students writing this proposal is caused by the unavailability of quality teaching materials in schools. The class XI students of SMA N 1 Padang Ganting, concluded that students only use one Indonesian language textbook that they can borrow from the school library. The textbooks used by these students only include an outline of the explanation of the learning material. The language used in the book also less communicative with students because many use terms that students don't understand. This causes often feel bored and not interested in reading the source book used. As a result, students' motivation to learn independently and actively becomes reduced. The variety of teaching materials currently in the school is only textbooks and worksheets that have not been integrated so there is a need to develop other teaching media, one of which is a module to encourage students to learn independently [5].

Therefore, one way that teachers can do to facilitate students is by providing teaching materials as one of the learning resources that will help students in achieving predetermined learning goals. One of the teaching materials that can be provided by the teacher is the learning module. Module is a book written with the aim that students can learn independently without or with the guidance of the teacher. The module is a package of teaching and learning relating to one unit of learning material [6].

Modules are learning packages that are related to a unit of learning material, and can be studied independently. Module embodiment can be in the form of printed material to be read 
subject learning and printed material plus assignments [7]. With modules, students can reach the level of mastery (complete) by learning individually. Students cannot proceed to the next unit of study before reaching complete level.

In making learning modules [8], the teacher must pay attention to the advantages of the learning module and adapt it to the characteristics of the material, students, and the potential of the school.

In preparing the learning module, the teacher needs to pay attention to the model of compiling or organizing the learning material that will be delivered. One model for organizing or organizing the learning material is to use the Problem Based Learning (PBL) model. PBL is a learning model that starts from a problem as a focus [9]. The use of problem oriented module will guide students to search for problem solving independently and this will provide a concrete experience in problem solving so that it fosters and trains high-level thinking skills including critical thinking skills [10]. The application of problem-based learning models that have been carried out in Indonesian language lessons KD writes a single cycle proposal and the second cycle shows an increase in student learning outcomes in terms of mastering the proposal writing material, and students are more courageous in arguing while discussing [11].

Thus, the problem-based learning model is a learning model by exposing students to practical problems as a foothold in learning. In other words, students learn through problems that are contextual or actually occur in their real life. The PBL model uses learning with environmental exploration that is used in the form of daily experiences of students so that they can lay real foundations for thinking [12]. Therefore, this study aims to develop learning modules based Problem Based Learning in writing proposals that are valid, practical, and effective for use in class XI SMA/MA.

\section{RESEARCH METHOD}

This type of research is the development of research (R\&D).In this study, development was carried out using a 4-D development model (four-D models) [13]. 4-D model of the development consists of four stages, namely the define, design, develop, and dissemination. In this study, only done through the development stage. In the definition phase, carried out the determination of the terms of the learning by analyzing the material standards of competence and learning materials based on the Kurikulum 2013. Phase define done through three steps, namely the curriculum analysis, concept analysis, and analysis of the students. The design phaseaims to create a learning module based Problem Based Learning model. Stage of development aims to produce Indonesian learning modules that can be used in the trial. This stage consists of the following. First, module validation test. Validation aims to examine the feasibility of module content, language, presentation and graphics. Module validation is carried out by experts from this field of study. Suggestion validator is used to improve the module developed. Second, the module practicality test. After the module is validated by the validator and declared valid, the next step is to test the module's practicality. This activity was conducted to determine the ease of use of the module and the efficiency of the use of modules by the teacher along with the students. Third, test the effectiveness of the module.

The subject of field trials in this study was limited to students of class XI IPA 1 in SMA N 1 Padang Ganting, amounting to 21 students. The type of data in this study is quantitative data. The data is obtained from the results of the validation sheet by experts; practicality sheet of problem based learning modules given to practitioners, namely teachers and test subjects. In addition, quantitative data also comes from the results of performance tests writing proposals by students and observation sheets. 
Data groups analyzed by descriptive statistical in the study were divided into validation sheet data, practicality sheets, student learning outcomes, and student activities in the form of observation sheets using the learning module based PBL to writeproposals. In this study, data analysis was divided into three, namely as follows. First, analysis of the validity and practicality of the product. In analyzing the validity and practicality of the product, it is done by analyzing the questionnaire data sheet validation and practical sheets. This questionnaire for validation and practical sheets was analyzed using a Likert scale. Second, analysis of product effectiveness test data. Data on student learning outcomes in the form of performance tests, analyzed by steps, namely examining the results of proposals that have been written by students in accordance with predetermined indicators of proposal writing; give scores based on proposals written by students using the assessment rubric to write a proposal; process value [14]; qualify data, namely grouping data on the ability to write proposals; and calculate the average.

In addition, data obtained through supporting instruments, namely in the form of observation sheets, are analyzed by the following steps. First, calculate the percentage of student activity in each aspect observed using the percentage activity formula [15]. Second, calculate the average. Third, qualifying the average percentage.

\section{RESULTS AND DISCUSSION}

The first stage of this research is to define. At the defining stage, curriculum analysis, concept analysis, and student analysis are carried out. The following will explain the three stages of the analysis. In terms of curriculum analysis, in this study, curriculum used as a reference was Kurikulum 2013. In its implementation, this material was divided into three learning activities or three meetings. Each meeting stipulates several learning indicators. The indicators that have been developed are used as a reference in the formulation of learning objectives. From the results of the analysis of KI, KD, and indicators, the learning objectives set are as follows. First, after studying learning activities 1, students are able to describe the understanding, purpose, and types of proposals appropriately. Second, after studying learning activities 1, students are able to describe the elements of the proposal correctly. Third, after studying learning activities 2 , students are able to describe the things that must be considered when writing the proposal appropriately. Fourth, after studying learning activities 2 , students are able to write activity proposals by paying attention to matters that need to be considered in writing the proposal appropriately. Fifth, after writing proposals in groups, students are able to present proposals that have been written in front of the class and other students are able to comment on the results of the proposals that have been presented correctly.

Learning objectives 1 and 2 are learning objectives found in learning activities 1 or at the first meeting. Learning objectives 3 and 4 are learning objectives found in learning activities 2 or at the second meeting. Learning objectives 3 are learning objectives found in learning activities 3 or at the third meeting. Based on the results of the analysis of the indicators and learning objectives, it can be concluded that to achieve Basic Competence, students must first master the nature of the proposal. After students are able to master the nature of the proposal, students are assigned to write proposals. After that, the written proposal was presented to the front of the class to get input from the teacher and friends.

After curriculum analysis, the next step is to carry out concept analysis. Concept analysis aims to identify, detail, and formulate the main concepts that will be presented in the material writing the proposal on the module. Based on the indicators and learning objectives that have been developed, the main concepts of the proposal writing material can be determined. The 
main concepts of the proposal writing material include the understanding of the proposal; the purpose of proposal writing; types of proposals; elements of the proposal; things that must be considered when writing a proposal; and examples of activity proposals.

Next, an analysis of students is carried out. Student analysis aims to determine the characteristics of students who are the subjects of research. Student analysis is also used as a basis for developing learning modules that are appropriate to the conditions and characteristics of students. Students who are the subject of research are students of class XI IPA 1 SMA N 1 Padang Ganting which has a range of ages 16 to 18 years. According to Piaget's theory, students aged 16 to 18 or during high school are at the formal operational stage [16]. At the formal operational stage, students have been able to think abstractly, reason logically, and draw conclusions from available information. At the formal operational stage, students are able to integrate the things they have learned with challenges in the future and make plans for the future. At this stage, it can be said that students already have problem solving that is truly scientific, and it is possible to conduct hypothesis testing with certain variables.

Students of class XI IPA 1 who were the subjects of this study were students who were quite smart students. This can be seen from the class average obtained by this class. When compared to other classes of the same level, this class is the class that has the highest average. In addition, this class is also a class that has high learning motivation. Based on the results of observations of student writing, namely proposals that have been written by students, it can be said that students in this class are students who have not been skilled at writing proposals. Students in this class feel happy and excited when discussing lessons related to numbers and formulas, but not learning that requires writing skills. The characteristics of science students who like to solve a problem make the researcher choose the Problem Based Learning model to be used as a model in creating learning modules.

The second phase of this research is the design phase problem based learning modules. At this stage, arrangements are made starting from the start page to the end of the learning module. The design of problem-based learning modules in this study, namely module cover, introduction, table of contents, instructions for using modules, KI, KD, indicators, and learning objectives (competencies to be achieved), learning materials, supporting information, learning summaries, test exercises understanding, feedback, and reference list.

The third stage of this research is the develop stage. In this study, modules that have been designed, validated by 4 experts. In this study, the number of validated aspects is 4 aspects, namely the aspects of feasibility of content, language, presentation, and graphics. From the results of the analysis that has been done on the expert validation questionnaire, it can be obtained that the overall module validation scores an average is 95,53 with very valid categories. The description of the validated aspects is as follows. First, on the aspect of content eligibility, the average percentage is 94,21 . Second, in the aspect of linguistic feasibility, in the aspect of linguistic feasibility, the average percentage is 98 . Third, in the aspect of presentation feasibility, the average percentage is 95,24 . Fourth, on the aspects of graphics, the average percentage is 94,67 . The four average values of the validated aspects fall into a very valid category.

After validity testing, the next step is to test the practicality of the learning module. The trial took place for three meetings. Implementation of this trial was conducted to determine the practicality and effectiveness of the modules developed. The practicality test is divided into two, namely practicality by teachers and students. The results of the module practicality analysis by teachers and students cover two aspects, namely aspects of ease of use and conformity with time. The results of the module practicality analysis by the teacher are as follows. First, for aspects of ease of use, obtain a value is 90,91 in a very practical category. 
Second, for the conformity aspect with time, get a value is 80 in a very practical category. Thus, the average value of module practicality by the teacher is 85,46 with a very practical category. The results of the module practical analysis by students are as follows. First, for aspects of ease of use, obtain a value is 85,63 with a very practical category. Second, for the conformity aspect with time, the score is 78,57 in the practical category. Thus, the average value of module practicality by students is 82,1 with a very practical category. Then, it can be concluded that the module developed has been categorized as very practical.

After analyzing the module validity and practicality, the next step is to test the effectiveness of the learning module. The effectiveness test of the learning module is divided into two things, namely the results of the effectiveness of the module seen from the learning outcomes and the effectiveness of the module seen from the activities of students. Based on the results of the analysis of student learning outcomes, namely an analysis of the scores of proposals that have been written by students, we can conclude the following. First, of the 21 students who were the subjects of the study, there were 7 students who had very good qualifications; 11 students who have good qualifications; and 3 students who have grades with more than enough qualifications. Second, of the 21 students who were the subjects of the study, there were 2 students who did not meet the minimum learning completeness criteria with the module, which was 75 . This can be seen from the values obtained by the two students. Both students only obtained scores of 67,3 and 71,3 . Then, it can said the percentage of students who complete, which is $90,48 \%$ and the percentage of students who have not completed, which is $9,52 \%$. Third, based on the average value obtained classically, it can be said that the class which is the subject of the study has been completed classically even though there are still 2 students who have not met the minimum completeness criteria. This can be seen from the class average value, which is equal to 81,9 which is in the good qualification. Based on this, it can be said that students of class XI IPA 1 have met the completeness criteria in a classical manner, but have not met individual completeness criteria. For individuals who still do not meet these minimum completeness criteria, they must repeat to re-read the learning module, especially in parts that have not been mastered and also return to work on evaluations, namely writing proposals.

To analyze student activities during the activity, it was carried out using an observation sheet. In this study, the observer were two people, namely the Indonesian language teacher class XI IPA 1 in SMA N 1 Padang Ganting and the researcher as the second observer. In this study, the technique used to observe student activities is to divide students into two groups. Observations are made at each meeting, starting from the first meeting to the third meeting. The activities observed were 9 activities. Based on the results of the analysis of the observation sheet of student learning activities for three meetings, the average value of overall student activity was 78,31 with the active category.

Based on the results of the research that has been conducted, it can be said that the learning module based Problem Based Learning for writing proposal for students of class XI SMA/MA that has been developed, classified as valid, practical, and effective. In addition, the Problem Based Learning model can generate student problem solving skills. This can be seen from various problems as outlined in the learning module. These problems can be solved by students to have improved students' critical thinking skills.

Using PBM (Problem Based Module) can help improve learner's problem solving skills and their achievement in the subject. The level of problem-solving abilities, achievement, and learning products can be seen as higher in the experimental group compared to the control group. PBM is focused on problem solving, in which students try on their own problems and information in order to solve the problems [17]. 
Problem based learning requires students to be more very active. In problem based learning, students are involved directly in investigations and find solutions to problems so that eventually students are helped to become autonomous learners who are able to help themselves, in solving problems they face. Besides learning based on problems that involve students in their own choice of inquiry, it allows students to interpret and explain real world phenomena and build their understanding of the phenomenon [18]. Problem Based Learning model use constructivism theory as the basis. Students are able to identify and even be able to solve the problems given in accordance with students brain abilities so that this learning model is able to improve students critical thinking [19]. This is also supported by the results of Oktaviana's research that critical thinking skills and learning achievements of class XI IPA 2 SMA 1 Gondang in 2014/2015 students can be improved by applying constructivism learning approaches through PBL models equipped with a problem based learning module [20].

Based on the results of the research, found difficulties from the development of learning modules based on PBL. The difficulties experienced are in terms of presenting the problems contained in real life students into the learning module. The problem presented must be a complex problem and be able to demand students to do the problem solving process. With this problem solving, the model is Problem Based Learning only suitable for students with high levels of problem solving. In other words, the model is Problem Based Learning suitable to be applied to students who are capable of investigating the problems given. In this case, the teacher must be able to guide students in carrying out the problem solving process [21]

If the teacher will use the PBL model, then the learning material must be chosen which is much related to the real life every day. So, the teacher will easily arrange the problems to be proposed. The problem is in the form of non routine questions so that it can provide opportunities for students to conduct investigations to solve problems. If the teacher will use the PBL model, it will be more suitable for high-class students [22]. One of the shortcomings of the PBL model preparation of learning (tools, problems is the complex, concepts)

\section{CONCLUSIONS}

Based on the discussion, the following matters can be concluded. First, the learning module developed is classified as very valid. This can be seen from the value of module validity which is equal to 95,53 with a very valid category. Second, the learning module developed is classified as very practical. This can be seen from the practicality value of the module by the teacher which is equal to 85,46 with a very practical category and the practicality of the module by students that is equal to 82,1 in the very practical category. Third, the learning module developed is classified as effective. This can be seen from the results of the analysis of student learning outcomes, namely the learning outcomes of writing proposals, it can be concluded that classically, the average student learning outcomes is 81,9 which is in good qualification and based on the results of the observation sheet students, obtained an average is 78,31 in the active category. Thus, the module that has been developed is a module that is valid, practical, and effective and can be used in the process of learning writing proposal material for class XI students of SMA/MA.

\section{REFERENCES}

[1] Dalman, “Menulis Karya Ilmiah”,Jakarta: PT Raja Grafindo Persada, 2012.

[2] Susanto, Happy, "Panduan Praktis Menyusun Proposal", Jakarta: Visimedia, 2008. 
[3] Sujito, "Peningkatan Kemampuan Menulis Proposal melalui Penggunaan Strategi Jigsaw pada Siswa Kelas XI IPA,” vol. 3, no. 1, pp. 44-58, 2018.

[4] A. Rahayu, "Upaya Meningkatkan Kemampuan Menulis Proposal Bahasa Indonesia Melalui Pembelajaran Model Tandur Kelas XII Pemasaran SMK Negeri 2 Kota Blitar," Cakrawala Pendidikan, vol. 21, no. 1, pp. 1-11, 2018.

[5] EA Muhafid, NR Dewi, and A. Widiyatmoko, "Pengembangan modul IPA terpadu berpendekatan keterampilan proses pada tema bunyi di SMP kelas VIII," Unnes Sci. Educ. J., vol. 2, no. 1, pp. 140-148, 2013.

[6] Sumiati dan Asra, "Metode Pembelajaran", Bandung: CV Wacana Prima, 2007.

[7] Y. Ayriza, "Pengembangan Modul Bimbingan Pribadi Sosial Bagi Guru Bimbingan Konseling Untuk Menghadapi Bencana Alam," J. Kependidikan, vol. 39, no. 2, pp. 141156, 2009.

[8] Asyhar, Rayandra, "KreatifMengembangkanMediaPembelajaran". Jakarta: Gaung Perasada (GP) Press, 2011.

[9] Eggen, Paul and Don Kauchak, "Strategies and Models for Teachers: Teaching Content and Thinking Skills, United States of America: Pearson Education, Inc, 2012.

[10] I. Suarsana and G. Mahayukti, "Pengembangan E-Modul Berorientasi Pemecahan Masalah,” J. Pendidik. Indones., vol. Volume 2, no. 2, pp. 264-275, 2013.

[11] D. Susanto, "Meningkatkan Hasil Belajar Bahasa Indonesia Materi Menulis Proposal dengan Menggunakan Model Pembelajaran Berbasis Masalah Kelas XI IPS 1 SMA NEGERI 02 BATU TAHUN AJARAN 2012-2013,” 2013.

[12] R. dan EWLF Rahayu, "Pengembangan Perangkat Pembelajaran IPA Berbasis ProblemBased Learning di SMP," J. Kependidikan, vol. 45, no. 1, pp. 29-43, 2015.

[13] Thiagarajan, Sivasailam, Dorothy S. Semmel, dan Melvyn I. Semmel, "Instructional Development for Training Teachers of Exceptional Children".Indiana:Indiana University Bloomington, 1974.

[14] Purwanto, "Evaluasi Hasil Belajar".Yogyakarta: Pustaka Pelajar, 2011.

[15] Sudijono, A., "Pengantar Statistik Pendidikan", Jakarta: Raja Grafindo Persada, 2015.

[16] Monks, FJ dkk, "Psikologi Perkembangan: Pengantar dalam Berbagai Bagiannya". Translated by Siti Rahayu Hadinoto, Yogyakarta: Gadjah Mada University Press, 2002.

[17] W. Syafii and RM Yasin, "Problem Solving Skills and Learning Achievements through Problem-Based Module in Teaching and Learning Biology in High School," Asian Soc. Sci., vol. 9, no. 12 SPL ISSUE, pp. 220-228, 2013.

[18] PNJM Sinambela, "Kurikulum 2013, Guru, Siswa, Afektif, Psikomotorik, Kognitif" ejournal Univ. Negeri Medan, vol. 6, pp. 17-29, 2013.

[19] EK Dewi, "Pengaruh Penggunaan Model Pembelajaran Problem Based Learning Terhadap Kemampuan Berpikir Kritis Siswa pada Mata Pelajaran PPKn Kelas X SMAN 22 Surabaya," vol. 2, pp. 936-950, 2015.

[20] IA Oktaviana, ANC Saputro, and B. Utami, "Upaya Peningkatan Kemampuan Berpikir Kritis dan Prestasi Belajar Siswa melalui Penerapan Model PBL dilengkapi Modul pada Materi Kelarutan dan Hasil Kali Kelarutan Kelas XI SMA Negeri 1 Gondang," J. Pendidik. Kim., vol. 5, no. 1, pp. 143-152, 2016.

[21] K. Saddhono, "Cultural and social change of foreign students in Indonesia: The influence of Javanese Culture in Teaching Indonesian to Speakers of Other Languages (TISOL)." IOP Conf. Ser.: Ear. and Envi. Sci.. vol. 126 no. 1 IOP Publishing, 2018.

[22] VN Agustin, "Peningkatan Aktivitas dan Hasil Belajar Siswa Melalui Model Problem Based Learning (PBL),” J. Elem. Educ., vol. 2, no. 4, pp. 36-44, 2013 